\title{
Community Perceptions of Talawi District against Regional Head Elections as a Means to build Local Democracy
}

\author{
Ananda Mahardika1, Faizal Hamzah Lubis ${ }^{2}$ \\ ${ }^{1,2}$ Universitas Muhammadiyah Sumatera Utara, Indonesia \\ anandamahardika@umsu.ac.id
}

\begin{abstract}
Regional head elections (Pilkada) are one of the means used to demonstrate the democratic value of a government. Practically the activities and actions that apply in the pilkada are adopted from the general election system prevailing in Indonesia. Therefore, the pilkada is expected to be able to form local democracy in the regions. However, the facts show that the implementation of the pilkada actually shows the apathy of the people in the elections. According to the author's observations, the apathy of the people in the elections is inseparable from the perceptions formed by the community towards the pilkada. This perception then shapes people's behavior that distorts the objectives of the pilkada as a means of building local democracy in the region. Therefore this study aims to see how people's perceptions of the pilkada as a means of building local democracy. Especially in the Talawi subdistrict, Batu Bara Regency. In this study the authors used quantitative research methods to measure people's perceptions of the elections as a means of building local democracy in the regions. From the results of the research conducted, it can be seen that the people of Talawi sub-district give negative perceptions of the pilkada. The community doubts the ability of the pilkada as a means of building local democracy in the region.
\end{abstract}

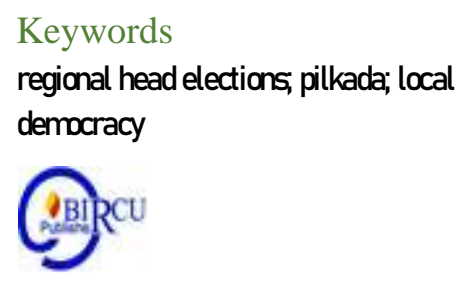

\section{Introduction}

In essence, regional head elections (PILKADA) are a system created to build local democracy in the regions. This local democracy is the basis for various political activities of the community on a small scale that are more regional in nature. Through this small scale, it is hoped that it will be able to capture total community political participation so that the political learning process carried out can reach down to the grassroots level of the community, and its output. is political maturity. Pilkada also gives full sovereignty to the people to fully exercise their rights in appointing their leadership in the regions. This direct election process will capture a leader who is in accordance with the wants and needs of the community.

Since its inception in 2005, the regional head elections have immediately experienced various kinds of problems and dynamics in each implementation. It is noted that there are several regions that have problems with the implementation of regional elections such as North Maluku, East Java, South Bengkulu and other areas. These problems usually include the implementation of non-transparent and unaccountable regional elections, money politics, up to voting. And in the end all these problems will lead to conflicts both vertically and horizontally. but as a new system, of course there must be adjustments to the system. Because 
in fact, the pilkada is a system that contains values that can build democracy, both on a local and national scale. The values consist of:

\section{People's political education}

Direct Pilkada provides understanding to the public about the role of public debate, the candidate selection system and the importance of work programs (vision and mission), policies, planning, and budgets in a democratic system. From this political education process, it is hoped that the public will be more rational in choosing candidates and responding to the regional election process and at the same time becoming a bridge for young people to pursue a career in politics.

2. Direct PILKADA is a means of training (ground training) and the development of democracy in a country

The direct pilkada system opens opportunities for people to participate politically either in the context of electing or the possibility to be elected in a political office.

3. Direct local elections as preparation for an advanced political career

Direct Pilkada creates a foundation for prospective political leaders at the local level to develop skills in policy making, running political parties and drafting budgets. It is hoped that the leaders at the local level will be able to produce reliable national politicians.

\section{Build political stability and prevent speratism}

People's participation in formal politics through direct regional elections can increase public trust in local governments, in this way it is hoped that social harmony, kinship spirit and social political stability can be achieved. This means that national political stability starts from local political stability and in the end political stability will distance a country from forms of speratism.

\section{Political equality}

According to Robert Dahl in Prihatmoko (2005: 137), local democracy will encourage people around the government to participate rationally in political life. With direct pilkada, political equality between various components of society will be realized.

\section{Prevent the concentration of power in the center}

Political equality and political participation will reduce the likelihood of concentration of power. With direct pilkada, political power will be widely distributed so that pilkada is a mechanism that can include the poor and marginalized groups as well as women.

\section{Public Accountability}

Public accountability is strengthened because pilkada is directly more accessible to the local population and therefore elected regional heads will be more accountable to policies and outcomes than national political leaders or government officials.

8. Increase the sensitivity of the elite to the needs of the community

The sensitivity of the government will increase because the head of government is placed appropriately, by direct election, to find out local needs and how these needs can be met effectively. In direct regional elections, candidates do not understand and have sensitivity to regional problems and society, tend not to be accepted. Therefore, candidates in the direct 
election will compete not only to sell an image of dignity, elegance, honesty and fairness, but also understand the needs of society.

In its implementation, Pilkada is held by KPUD (regional general election commission) institutions both at the provincial and district / city levels, where the KPUD is supervised by the central KPU's authority. This form of direct Pilkada clearly gives a new color to democratic life in Indonesia. History shows that the first direct local election was held in Indonesia in 2005. Since the first time it rolled around, until now the regional elections in Indonesia have raised various interesting phenomena to observe. Pilkada, which should be a tool to attract leaders who have a good level of integrity and capability, are actually used as a means to fight for positions and power in the regions.

\section{Review of Literatures}

\subsection{Definitio of Perception}

Perception is a process where individuals organize and interpret their sensory impressions to give meaning to environment they. Behavior individuals are often based on their perceptions of reality, not on reality itself. A perception is preceded by a sensing process, which is a stimulus received by the individual through the receptor, namely the senses. The sense organs are a link between the individual and the world outside. Perception is a stimulus that is sensed by the individual, organized then interpreted so that the individual realizes and understands what is sensed. In other words, perception is a process that involves the entry of messages or information into the human brain. Perception is an integrated state of the individual towards the stimulus it receives. What is in the individual, thoughts, feelings, individual experiences will be actively involved in the process of perception.

Gibson, et al (1989) in the book Organization and Behavioral Management, Structure; providing a definition of perception is a cognitive process that is used by individuals to interpret and understand the world around them (towards objects). Gibson also explained that perception is the process of giving meaning to the environment by individuals. Therefore, each individual gives meaning to the stimulus differently even though the object is the same. The way the individual sees a situation is often more important than the situation itself.

From this opinion it can be concluded that understanding of perceptionis a sensing process, the stimulus received by the individual through the senses which is then interpreted so that the individual can understand and understand the stimulus it receives. The process of interpreting this stimulus is usually influenced by individual experiences and learning processes.

\subsection{Perception Requirements}

Perception is a mental process to identify, evaluate, and respond any situation around. Knowledge, experience, and socio cultural orientation will define image and perspective of the problems. The difference of experience, analysing and knowledge, a framework describes the result of perception among individuals are different. (Sandi et al, 2020). Perception is a view that is preceded by sensing of objects (objects, humans, ideas, symptoms and events) through the five senses so that it immediately gives meaning and value to an object by highlighting the nature typical of an object and the results of perception can be in the form of responses or judgments that are different from individuals. (Ismail et al, 2020). Jalaludin Rakhmat argued that "Perception is the experience of objects, events or relationships obtained by inferring information and interpreting messages. According to him there are several conditions that cause a person's perception of something, consisting of: 


\section{a. Physical Requirements}

Everything that exists from around an individual that stimulates his senses, which can be: humans, objects or events, as well as everything that can be heard, smelled, touched and felt, including physical.

\section{b. Physiological Requirements}

Completeness of the organs owned by the individual responds to all incoming stimuli: sensory organs, sensory nerves and the brain. Consciousness occurs as a result of sensing the incoming stimulus, then received and transmitted by the sensory nerves to the brain structure until an awareness occurs. Each sense organ has its own characteristic and level of sensitivity in responding to a stimulant as F. Patty: "The same physical stimulant stimulates different sensory organs and different types of stimulant stimulate the same sense organs can cause the same sensing."

\section{c. Psychological Requirements}

Psychological requirements include need, readiness and attention. These three factors have a close relationship, namely the intensity level of perception indicates the intensity of need and readiness and vice versa (Rakhmat, 2002: 52)

\subsection{Pilkada}

Based on article 1 (paragraph 1) Indonesian repubelik government regulation number 6 of 2005 concerning the election, ratification, appointment and dismissal of regional heads and deputy regional heads juncto government regulation number 49 of 2008 concerning amendments to regulations on PP number 6 of 2005 Pilkada is a means of implementing people's sovereignty in provincial and / or city regencies based on Pancasila and the 1945 Constitution to elect regional heads and deputy regional heads. According to Prihatmoko (2005) Pilkada is a democratic mechanisms in the context of recruiting regional leaders, where the people as a whole have the right and freedom to choose the candidates they support and the candidates to compete in the same playing field. The implementation of direct Pilkada is a democratic political practice which is based on the principles of direct, general, free, secret, honest and fair (according to the explanation of Law No. 12/2003 on general elections).

According to "Axel Hadenius" in Prihatmoko (2005: 112) says that an election including direct regional election is called democratic if it has a meaning or term that refers to three criteria, namely, openness, accuracy and effectiveness of elections. Openness has three purposes. Pilkada must be open to every citizen (universal suffrage), that there is a choice between various political alternatives in real terms (the competing candidates) and the outcome is not predetermined. Open citizen access means that suffrage is truly universal. All citizens are guaranteed to have the right to vote without discrimination. It is not a controversy or contradiction if the right to vote is limited by minimum conditions that must be met by residents such as age, physical and spiritual health, domicile and length of stay.

Openness also means the equal vote value of all citizens without exception. The principle commonly used is one man, one vote, one value. All citizens are counted the same. The criteria regarding accuracy aim at voter registration and identification, election campaigns and procedures in a more stringent sense, namely that all candidates must have equal access to state and private media based on the same legal standards, state officials must be politically neutral during the holding of Pilkada. Pilkada effectiveness means that predetermined political positions must be filled through an election mechanism (direct 
pilkada) and these positions must be able to represent voters in the form of pro-people policies.

\section{a. Pilkada from a Theoretical Perspective}

According to "David Easton" in prihatmoko (2005: 200), the first political theorist who introduced a systems approach in politics, stated that a system always has at least three characteristics. The three characteristics are (1) consisting of many parts, (2) the parts interact with each other and are interdependent and (3) have borders (boundaries) which separates from the environment which also consists of other systems.

As a system the pilkada has parts which are secondary systems (secondary system) or sub-sub system (sub system). These parts are electoral regulation, electoral process and electoral low enforcement. Electoral regulation is all provisions or rules regarding direct regional elections that are applicable and binding on prospective organizers, candidates and voters in carrying out their respective roles and functions. Electoral process is meant for all activities that are directly related to the pilkada which refer to statutory provisions, both legal and technical. Electoral low enforcement, namely law enforcement on regional election rules, whether political, administrative or criminal. The three parts of the Pilkada very much determine the extent to which the capacity of the system can bridge the achievement of the goals of the initial process.

The mechanism of procedure and procedure in direct regional elections is a dimension of electoral regulation. Technically, the parameters of the mechanism, procedure and procedure in the system are measurable (measurable). "Ben Reilly" in prihatmoko (2005: 202) installs the 3 measures which according to him are also complementary and inseparable. The three of them are (1) the electoral system translates the number of votes obtained in elections into seats, (2) the electoral system acts as a liaison vehicle that allows the people to hold the responsibility of the leader they have chosen, (3) the electoral system provides a boost to the parties. competing for influence in order to do it in different ways. In short, to obtain democratic direct election results, the process must also be democratic, which includes aspects of justice, openness and honesty.

On that basis, the direct election system is a group of elements that carry out activities or formulate a scheme or procedure for selecting a regional head. As a system, the pilkada system has characteristics, among others, it aims to elect a regional head, each component involved and the activity has a boundary, is open, is composed of various activities which are sub-systems, each activity is tied to each other and depends on a complete series, has a control mechanism and has the ability to adjust and adapt. In short, the core of the pilkada system is the dependency relationship between each component involved and between the activities that make up the system (interrelationship between parts).

\section{b. Pillkada Viewed From a Practical Perspective}

The regional head is a political position and a public position in charge of leading the bureaucracy to move the wheels of government. The functions of government are divided into protection, public services and development (protctive, public services and development). The regional head carries out the policy-making function of the three government functions. In the context of the power structure, the regional head is the regional chief executive.

The term public office implies that the regional head carries out a policy-making function that is directly related to the interests of the people (public) have an impact on the people and are felt by the people. Therefore, the regional head must be elected by the people and must be accountable for the trust that has been given to the people. As for political 
officials, it implies that the recruitment mechanism for regional heads is carried out by political mechanisms, namely through elections that involve political elements such as the people and political parties.

Pilkada is a political recruitment, namely the selection of figures who run for regional heads, both governors / deputy governors, and regents / deputy regents or mayors / deputy mayors in regional political life, pilkada is one of the activities, the value of which is equivalentwith the election of DPRD members. This equivalence is shown by the equal position between the regional head and the DPRD. The partnership relationship is carried out by carrying out their respective functions so that a check and balance mechanism is formed. Therefore, the pilkada is actually part of the regional political system.

The main actors of the pilkada system are the people, political parties and candidates for regional head. The three actors were directly involved in the activities carried out in a series of direct pilkada stages. The activities include:

1) Voter registration

2) Candidate Registration

3) Determination of candidates

4) Campaign

5) Voting and counting of votes and

6) Determination of prospective voters

Because the direct regional election is an implementation of participatory democracy, democratic values become a parameter for the success of the implementation of the activity process. These values are manifested through the principles of direct regional elections which generally consist of direct, general, free, secret, honest and fair. As an implication, the implementation process of the above activity stages must uphold and uphold the values of objectivity, openness, justice and honesty.

Political parties have a big interest in getting them elected so that it is impossible to leave the administration to them. Pilkada records so far show that the implementation of the pilkada by political parties creates a democratic bias such as conspiracy, nepotism and money politics. Therefore these activities must be carried out by institutions that are strictly regulated to maintain and guarantee the implementation of the values of objectivity, openness, justice and honesty. The institution must be independent, independent, nonparticipant, and free from political interests in order to guarantee the implementation of each activity in an orderly and fair manner.

To optimize these objectives and functions, it is necessary to have an institution that formally oversees the implementation of the stages of these activities. The term optimizing means that the tasks that are carried out for the stages of activities are carried out as well as possible according to the criteria of democracy and statutory provisions. Therefore, structurally these institutions are part of the organization but are autonomous, independent and non-partisan. If the structure is above or supervising the organizer, the existence of an institution can cause this to happendeadlock (deadlocked) the election process, if the optimization of the stages of activities that are hampered is interpreted as an error that must be stopped. On the other hand, if they are under or become part of the regional elections but are not autonomous, the optimization goal will not be achieved because they are easy to intervene and co-opt. For this reason, in some developed countries an election oversight institution was not formed because the organizers were truly autonomous, independent and non-partisan.

Democratic elections can be described as shown below. The flow of input does not flow solely from political parties but also from groups outside political parties. Candidates for regional head come from political parties or individuals outside of political parties. They 
undergo a process, namely completing the stages of activities starting from researching candidate requirements, campaigning, voting and counting votes to determining the elected candidate. During the registration period, candidates submit requirements to be examined by the organizer. Such research is purely administrative in nature, so it is often referred to as administrative selection. During the campaign period, candidates compete to win people's sympathy by offering a vision, mission and work program.

Table 1. Democratic Election Input Flow

\begin{tabular}{|c|c|c|c|}
\hline \multicolumn{4}{|c|}{ The Organizer } \\
\hline $\begin{array}{l}\text { - Party } \\
\text { - Public } \\
\text { - Feedback }\end{array}$ & $\begin{array}{l}\text { Candidat for regional } \\
\text { head / deputy } \\
\text { regional head }\end{array}$ & $\begin{array}{l}\text { 1. Voter registration } \\
\text { 2. Campaign } \\
\text { 3. Voting } \\
\text { 4. Vote count } \\
\text { 5. Determination of } \\
\text { elected candidates }\end{array}$ & $\begin{array}{l}\text { Regional head I } \\
\text { deputy regional head }\end{array}$ \\
\hline
\end{tabular}

\subsection{PILKADA Democracy Parameters}

Regional heads and deputy regional heads, governors / deputy governors, regents / deputy regents and mayors / deputy mayors are public positions in which democratic (open and accountable) mechanisms and values are attached to the election process, accountability for duties, and dismissal.

The regional head election mechanism is called democratic if it meets several parameters. Quoting the opinion of "Robert Dahl", "Samuel Huntington" (1993) and "Bingham Powel" (1978), in Afan Ghaffar and friends, the parameters for observing the realization of democracy include:

1. General election

Recruitment of political or public positions must be carried out by general elections, with general elections (elections) being held regularly with clear, competitive, honest and fair grace periods. Election is the first gate that must be passed because with elections democratic institutions can be formed. Then after the election, people will see and judge how much the elected public official has fulfilled his promises. Assessment of the performance of political officials will be used as provisions to provide rewards or punishments (reward and punishment) in an upcoming election. An official who does not fulfill his promises and does not maintain his morality will be punished by not being elected, on the other hand, an official who pleases the public's heart will be re-elected.

2. Rotation of power

Rotation of power is also a democratic parameter whether or not a recruitment of political officials is or is. Power rotation assumes that political power or jabtan cannot and cannot be held continuously by someone as in the monarchy system. In other words, democracy requires a regular and peaceful rotation of power or public office through a transparent and accountable election mechanism.

3. Open Recruitment

Democracy opens up opportunities to hold competitions because all people or groups have equal rights and opportunities. Therefore, in filling political positions such as regional heads, opportunities should be open to all those who meet the requirements, with fair competition in accordance with the agreed rules.

4. Public Accountability

Public office holders must be accountable to the public for what they do, both as individuals and public officials. A regional head of other political officials must be able 
to explain to the public why choosing policy A instead of policy B, why should increase taxes rather than make efficiency in government and eradicating KKN. What they do is open to public questioning. Likewise, what is done by his immediate family, relatives, and even close friends is often linked to the position or position of the official. This is because public officials are a mandate from the community, so they must maintain and maintain and be responsible for this mandate.

\subsection{Democracy}

Lexically democracy comes from the Greek language, namely "demos" which means the people and "kratos" which means authority or to rule. So in simple terms democracy can be interpreted as the authority of the people to rule or the people have the sovereignty to rule. Here the term democracy becomes a narrow term. , because it is only interpreted as a process " role the people"In ruling. Meanwhile, the whole regulations governing the displacement of the people are very unclear in that concept, as in the modern democratic concept.

In the 19th century the notion of democracy had just expanded again following the Schumpeterian tradition of thought. For him, in simple terms, democracy is a political method, a mechanism for electing political leaders. Citizens are given the opportunity to choose between one of the political leaders who are competing for votes. Between elections, decisions are made by politicians. In the next election, citizens can replace the representatives they chose previously. The ability among them to elect political leaders during the election period is called democracy. This means that democracy is interpreted as a full collective decision-making process through free, honest, and fair elections in order to elect candidates who have the right to hold political positions.

According to "Aristotle" in "Revitch" and "Thernstrom" (2005: 13) the foundation of a democratic state is freedom which in the opinion of people in general can only be enjoyed in such a state, this is recognized as the main goal of every democracy. One of the principles of freedom is that everyone in turn is obliged to rule and be governed, and indeed democratic justice is the application of equality, not proportion, from which it is concluded that the majority must have the highest power and whatever the majority agrees must be objective and fair.

\section{Discussion}

\subsection{Talawi District Community Perceptions of Pilkada}

According to Jalaludin Rakhmatargues that "Perception is the experience of objects, events or relationships obtained by inferring information and interpreting messages. Based on this opinion, it can be seen that perception has a relationship with behavior formation. This is because the behavior shown by individuals is based on the message it interprets. Based on the findings in the field, in relation to people's perceptions of the pilkada, it can be seen that people give negative perceptions of the implementation of the elections. These negative perceptions are formed by facts related to the implementation of the pilkada. Referring to the opinion of David Easton who divides the electoral system into three parts consisting of electoral regulation, electoral process, and electoran low enforcement. In the practice of organizing the three parts of the system, the three parts of the system did not run optimally so that the public showed a dubious perception that the pilkada was a system capable of building local democracy in the region. According to the community in the electoral regulation section, the rules contained in the pilkada are not yet binding, because in practice many regulations can then become flexible, such as determining the number of retained earnings, determining candidates and applying sanctions. This causes people to doubt the ability of the 
elections to build local democracy in the region. In the electoral process, the community perceives the pilkada as a system that refers to a process that contains many elements of a bargaining position. For the people of Talawi sub-district, the statutory provisions in the pilkada system are only limited to normative formality which shows the legality aspects of the pilkada as an electoral system. However, these rules do not become guidelines that must be obeyed absolutely. The Talawi sub-district community also perceives law enforcement in the pilkada as still weak, various violations in the implementation of the elections only end in administrative sanctions, although there are criminal sanctions in these violations but do not reflect objective and transparent law enforcement.

The regional head election mechanism is called democratic if it meets several parameters. Quoting the opinion of "Robert Dahl", "Samuel Huntington" (1993) and "Bingham Powel" (1978), in Afan Ghaffar and friends, the parameters for observing the realization of democracy in regional elections can be seen through four aspects including general elections, rotation of power., open recruitment, and public accountability. In this study, the authors found that the people of Talawi sub-district gave negative perceptions of these four criteria. The people of Talawi sub-district perceive that the concept of general elections contained in the pilkada is not a democratic system. The public doubts the pilkada as a recruitment system that is competitive, direct, public, free, confidential, honest, and fair. The public points to the fact that the pilkada is followed by pairs of candidates who have poor track records in government, but can still be passed in the pilkada candidacy. In addition, the community also doubts that the pilkada is a system that can be a means of rotating power in the regions. This can be proven by the victory of the incumbent pair in the regional head elections even though the pair did not have achievements in the field of government and regional development.

The public also perceives the pilkada as a biased political recruitment system. On the one hand, the requirement is to provide an open, fair, and equal opportunity to any person or group to participate in the election contestation. However, in practice there are many rules that are considered by the community to be partial to certain people or groups. According to the community, the aspect of public accountability in the regional elections is still weak. The number of violations that occurred in the practice of organizing the pilkada caused people to doubt the ability of the pilkada to produce regional heads who were capable of carrying out government duties in a professional and responsible manner in their electoral area.

This public perception ultimately influences people's behavior in the pilkada. The community became apathetic towards the local elections. The community did not actively participate in the pilkada. Pilkada is only able to involve community participation to exercise their voting rights. But has not been able to become a means of building local democracy in the region.

\subsection{Pilkada and Establishment of Local Democracy}

Pilkada is a means of political education for people in the area. According to Kartono (1996: 63) political education is also referred to as political forming or politische bildung. It is called forming because it contains an intense way to form political people who are aware of their political status or position in the midst of society. And it is called bildung (formation or self-education), because the term concerns the activity of forming oneself, with full awareness and own responsibility to become a political person. Political education is not meant to educate someone to become a political intellectual but rather an educational activity that emphasizes on the formation of a person, so that the person concerned is better able to understand himself and the situation of the environment around him. Then able to assess 
everything critically, to further determine attitudes and ways of handling various problems that exist in the middle of his / her environment.

Through this political education, someone will try to see the socio-political problems around him in other ways, then discuss, think about, and participate in dealing with or solving in other ways. Thus political education is a learning process, not just adding information and knowledge but rather emphasizing critical insight into the situation, determining the right attitude and training dexterity in action.

This political education is processed through the political participation of the community in the regional elections. According to Miriam Budiardjo (1998: 1) political participation is the activity of a person or group of people to actively participate in political life, namely by electing the leadership of the State and directly or indirectly influencing government policy (public policy). This activity includes actions such as voting in general elections, attending general meetings, becoming a member of a party or interest group, establishing contact (contacting) with government officials or members of parliament and so on. And according to "Samuel P. Huntington" and "Joan M Nelson" in Budiardjo (1998: 2) political participation is the activity of citizens who act as individuals intended to influence decision-making by the government. Participation can be individual or collective, organized or spontaneous, steady or sporadic, peaceful or violent, legal or illegal, effective or ineffective. Political participation is meant not only to involve the community in general elections but more than that political participation that occurs will provide a political education process to the community. So that people become aware and understand their rights as citizens. The community is able to analyze and identify various needs and environmental conditions. Then the community becomes more responsive and critical of the policies and decisions made by the government. Through this process, it is hoped that a responsible local democracy will be built.

However, from the results of research conducted in the field, it was found that the public gave negative perceptions of the implementation of the pilkada. The public accepts intense facts about the implementation of the pilkada. This resulted in the reduction of the values of political education that existed in the pilkada. These negative facts also cause bias in democratic values in the Pilkada. So that these conditions make it difficult for the pilkada to become a medium for building local democracy in the region.

Pilkada has not been able to provide political education to the community. From the process of organizing the elections, the community was not taught to become politically mature. The community is not involved in discussions to determine criteria for competent candidates, the community does not chat with each other to come up with ideas related to solutions to problems that exist in the area. The public was more involved in gossip that discussed various frauds in the elections. As a result, people became passive towards the values of political and democratic education from the elections

The distortion of political and democratic values in the pilkada can be seen from the people's participation in the pilkada. Public participation in the regional elections is limited to being constituents who give their voting rights legally and correctly. However, the community does not have the participation to influence government policies that have been selected through the election process. Community participation ends after they exercise their voting rights in the voting booth. After the process of the pilkada stages is complete the community does not have the means or media to convey their aspirations to the regional heads who have been elected in the pilkada. So that this finding can be used as an indication that the regional elections have not been able to build local democracy in the area, especially in the Talawi sub-district. 


\section{Conclusion}

Conceptually, pilkada has values that are capable of building local democracy in this area. This can be proven by the various principles contained in the pilkada. Apart from that, the statutory regulations that serve as guidelines and the legal umbrella for the implementation of the pilkada provide ample space to encourage the creation of regional elections. However, in practice, the pilkada has not been able to instill the principles of political and democratic education in the people who are the subjects and objects of the elections. The implementation of rules and law enforcement in the elections is still vague. This condition led to the emergence of messages and negative impressions from the public regarding the implementation of the elections. These negative impressions and messages ultimately shape people's perceptions. This public perception has an influence on the behavior shown by the community in the pilkada. From the results of the research conducted, it is known that, negative perceptions about the pilkada lead people to behave apathetically towards the elections. So that this fact makes it difficult for the pilkada to become a means of building local democracy in the region.

\section{References}

Budiarjo, Miriam.(1998). Partisipasi dan Partai Politik, Yayasan Obor Indonesia, Jakarta Ismail, et al. (2020). The Community Perceptions of Poverty in Gampong Ayon, Seulimeum Sub-district, Aceh Besar Regency (Research Results on March 2017). Budapest International Research and Critics Institute-Journal (BIRCI-Journal). P. 270-275. Irtanto. (2005). Dinamika politik Lokal Era otonomi Daerah, Pustaka pelajar, Yogyakarta Kartono, Kartini. (1996).Pendidikan Politik, Mandar Maju, Bandung Prihatmoko, Joko. (2005)/ Pemilihan Kepala Daerah Langsung, Pustaka Pelajar, Yogyakarta

Prihatmoko J Joko. (2008). Mendemokratiskan Pemilu, Pustaka Pelajar, Yogyakarta.

Revitch dan Thernstrom. (2005). Demokrasi Klasik Dan Modern, Yayasan Obor Indonesia, Jakarta

Samiana, Retnaningsih, dan pulungan. (2006). Etika Politik dan Demokrasi, Pustaka Percik, Salatiga

Sandi, J. et al. (2020). Public Perception of the Implementation of Simultaneous Regional Head Election 2020 during Covid-19 Pandemic in Palangka Raya Regency. Budapest International Research and Critics Institute-Journal (BIRCI-Journal). P. 3333-3340

Sorensen George. (2003). Demokrasi Dan Demokratisasi (Proses dan Prospek Dalam dunia yang sedang Berubah), Pustaka Pelajar, Yogyakarta

Syahdan, gregorius. (2004). Jalan transisi Demokrasi Pasca Soeharto, pondok edukasi, Bantul 